\title{
Penggunaan Pektin Kulit Jeruk Manis (Citrus sinesis) sebagai Absorben untuk Mengurangi Kadar Ion Kromium (VI) pada Sampel Air Sungai Jagir
}

\author{
Zjahra V. Nugraheni ${ }^{*}{ }^{1}$; Wahyu P. Utomo; ${ }^{1}$ Qurrota A'yuni; ${ }^{2}$ Nur A. Agustina; ${ }^{1}$ Januar Kholik ${ }^{1}{ }^{\text {Chandra }}$ \\ Puspita $^{1}$ \\ ${ }^{1}$ Departemen Kimia, Institut Teknologi Sepuluh Nopember (ITS). Kampus ITS Sukolilo, Surabaya \\ ${ }^{2}$ Jurusan Teknik Kimia, Universitas Nahdlatul Ulama Sidoarjo
}

*Penulis korespondensi: zjahravianita@chem.its.ac.id

\begin{abstract}
Abstrak
Telah dilakukan penelitian mengenai kemampuan pektin kulit jeruk manis (Citrus sinensis) sebagai biosorben ion Cr (VI) pada sampel air sungai Jagir. Penelitian ini dilakukan untuk mengetahui daya serap optimum bubuk pektin sebagai biosorben pada ion $\mathrm{Cr}(\mathrm{VI})$ menggunakan AAS (Atomic Absorption Spectroscopy). Kadar ion Cr(VI) pada sampel sungai air Jagir sebesar 0,2532 ppm dengan suhu air $31^{\circ} \mathrm{C}$ dan $\mathrm{pH}$ 6,5. Setelah dilakukan absorbsi menggunakan biosorben bubuk pektin didapat daya serap untuk penyerapan ion $\mathrm{Cr}(\mathrm{VI})$ adalah $98.06 \%$ dengan variasi massa pektin sebesar 1,5 g dan waktu kontak selama 3 jam.
\end{abstract}

Kata kunci: Pektin, biosorben, ion Fe(III), ion Cr(VI).

\begin{abstract}
The ability of pectin from sweet orange peel (Citrus sinensis) as biosorbent of Cr (VI) ion in water of Jagir river has been done. This study was conducted to determine the optimum absorption pectin powder as biosorbent on Cr (VI) ion using AAS (Atomic Spectroscopy Absorpton). The compotition of Cr (VI) ion is $0.2532 \mathrm{ppm}$ with $31^{\circ} \mathrm{C}$ of water temperature of and $6.5 \mathrm{of} \mathrm{pH}$. After absorbtion process using pectin powder, absorption capacity of $\mathrm{Cr}(\mathrm{VI})$ ion is $98.06 \%$ with a variation of $1.5 \mathrm{~g}$ of pectin powder and 3 hours of contact time.
\end{abstract}

Keywords: Pectin, biosorbent, absorption, Cr(VI) ion metal.

\section{Pendahuluan}

Air merupakan sumber daya alam yang sangat penting bagi semua makhluk hidup. Air digunakan untuk berbagai keperluan mulai dari minum, mencuci, mandi, dan kegiatan-kegiatan vital yang lain [1]. Salah satu sumber air berasal dari sungai. Sungai merupakan salah satu sumber air yang memiliki peranan penting dalam pemenuhan kebutuhan masyarakat, yaitu sebagai sarana penunjang utama dalam meningkatkan pembangunan nasional dan transportasi yang 
relatif aman untuk menghubungkan antar wilayah [2]. Aktivitas dari kegiatan industri, rumah tangga dan pertanian akan menghasilkan limbah yang memberikan sumbangan pada penurunan kualitas air sungai [3]. Penurunan kualitas atau pencemaran air sungai tersebut diakibatkan oleh adanya unsur atau zat lain yang masuk ke dalam air [4]. Tingkat pencemaran sungai dapat mempengaruhi daya tampung sungai. Semakin tinggi tingkat pencemaran sungai, maka dapat mengurangi daya tampung atau bahkan dapat melampaui daya tampung sungai tersebut.

Jenis air dapat diklasifikasikan menjadi empat kelas, yaitu kelas I, II, III, dan IV. Kelas I merupakan air yang peruntukannya dapat digunakan menjadi air minum, dan atau peruntukan lain yang memprasyaratkan mutu air yang sama dengan kegunaan tersebut. Kelas II merupakan air yang peruntukannya dapat digunakan untuk prasarana/sarana rekreasi air, pembudidayaan ikan air tawar, peternakan, air untuk mengairi pertanaman, dan atau peruntukan lain yang mempersyaratkan mutu air yang sama dengan kegunaan tersebut. Kelas III merupakan air yang peruntukannya dapat digunakan untuk pembudidayaan ikan air tawar, peternakan, air untuk mengairi pertanaman, dan peruntukan lain yang mempersyaratkan mutu air yang sama dengan kegunaan tersebut. Kelas IV merupakan air yang peruntukannya dapat digunakan untuk mengairi pertanaman dan atau peruntukan lain yang mempersyaratkan mutu air yang sama dengan kegunaan tersebut [5]. Dari hasil penelitian yang telah dilakukan disebutkan bahwa air sungai di Surabaya mengandung logam berat salah satunya adalah kromium dengan konsentrasi DO (Dissolved Oxygen), BOD (Biochemical Oxygen Demand), COD (Chemical Oxygen Demand) melebihi nilai ambang batas sungai kelas I [6]. Sungai Jagir merupakan salah satu anak Sungai Brantas yang mengalir di Kota Surabaya. Sebagai salah satu sungai terpanjang di Jawa Timur, karakteristik limbahnya pun berbeda sepanjang aliran sungai. Di kota Mojokerto limbah domestik tercatat sebesar 54\% sementara untuk limbah industri sebesar 21\%. Memasuki Kota Surabaya, kontribusi limbah industri meningkat hingga $40 \%$. Berdasarkan penelitian, sedimen sungai Surabaya dari stasiun sampling Ngagel diperoleh data logam berat dengan satuan $\mathrm{mg} / \mathrm{kg}$ sebagai berikut $\mathrm{Hg}$ 0,342; $\mathrm{Cr} 40,0 ; \mathrm{Fe}$ 51000; Mn 1470; Cu 61,8; Ag 2,0 [6].

Akibat pencemaran air, Sungai Jagir berwarna keruh. Letak pintu air tersebut tepat disebelah Stasiun Kereta Api Wonokromo dan PDAM Surabaya. Air dari Sungai Jagir juga diolah menjadi Air PDAM dan dimanfaatkan untuk memenuhi kebutuhan air bersih warga Surabaya. Keputusan Menteri Kesehatan No. 907/MENKES/SK/VII/2002 [7] menetapkan bahwa syarat air minum harus jernih dan tidak berwarna. Sedangkan sungai Jagir di Surabaya masih tergolong 
keruh dan tercemar. Bantaran sungai Jagir telah banyak beralih fungsi menjadi perkampungan padat penduduk dan ratusan industri dari skala kecil sampai skala besar. Hal tersebut menjadi indikator bahwa sungai Jagir sekarang jauh dari kata layak menjadi bahan baku air PDAM.

Hasil penelitian yang dilakukan oleh Anggraini pada tahun 2012 [8] salah satu metode yang digunakan untuk adsorbsi ion kromium di limbah cair industri adalah menggunakan cara filtrasi pasir. Filtrasi pasir merupakan proses pemisahan zat-zat atau senyawa-senyawa kimia yang tidak dibutuhkan dengan menggunakan pasir sebagai media penyaring. Pada penelitian ini ditemukan bahwa persentase adsorbsi maksimum terjadi pada filtrasi dengan massa pasir sebesar $80 \mathrm{~g}$ yang dapat mengadsorbsi larutan kromiun (VI) sampai dengan $86 \%$.

Berdasarkan uraian di atas maka dibutuhkan bahan lain yang lebih efektif dan efisien untuk digunakan dalam pengolahan air sungai Surabaya utamanya aliran Sungai Jagir dari kandungan logam berat yaitu Krom. Untuk meminimalisir adanya ion atau senyawa berbahaya lain yang ikut larut dalam air, maka dapat digunakan media absorbsi dari bahan alam, yaitu menggunakan bubuk pektin. Pengolahan tersebut menggunakan biosorben bubuk pektin dari kulit jeruk manis. Penggunaan biosorben bertujuan untuk mengetahui daya serap optimum dari bubuk pektin dalam mengabsorb ion $\mathrm{Cr}(\mathrm{VI})$.

\section{Metode Penelitian}

\subsection{Pembuatan Biosorben Bubuk Pektin dari} Kulit Jeruk Manis (Citrus sinensis)

Kulit jeruk manis ditimbang sebanyak 1 $\mathrm{kg}$ dan dihaluskan dengan blender menjadi bubur pektin. Bubur pektin ditambahkan $\mathrm{HCl}$ $0,1 \mathrm{~N}$ hingga $\mathrm{pH}$ menjadi 1,5. Bubur pektin asam dipanaskan pada suhu $80{ }^{\circ} \mathrm{C}$ selama 40 menit. Filtrat yang diperoleh didiamkan hingga suhu ruangan. Filtrat tersebut kemudian ditambahkan dengan etanol asam (etanol: $\mathrm{HCl}$ ) dengan rasio 1:1,5 dan didiamkan selama 12 jam. Endapan pektin disaring dan dicuci menggunakan etanol 95\% hingga bebas klorida, kemudian dikeringkan pada suhu $40^{\circ} \mathrm{C}$ selama 8 jam menggunakan oven. Pektin kering digerus dan diayak hingga menjadi bubuk pektin yang homogen. Pektin kering dianalisa menggunakan FTIR untuk mengetahui apakah pektin terbentuk atau tidak.

\subsection{Pembuatan larutan stock Cr(VI) 100 ppm}

Larutan standar $\mathrm{Cr}^{6+} 100 \mathrm{ppm}$ dibuat dengan cara melarutkan $0,0565 \mathrm{~g} \mathrm{~K}_{2} \mathrm{Cr}_{2} \mathrm{O}_{7}$ dengan aqua DM dalam labu ukur $100 \mathrm{~mL}$.

\subsection{Pembuatan Kurva Kalibrasi Cr(VI)}

Larutan $\mathrm{Cr}(\mathrm{VI})$ dengan konsentrasi 1 ppm dibuat dari larutan stok $\mathrm{Cr}(\mathrm{VI}) 100$ ppm. Larutan standar Cr(VI) 100 ppm diambil 1 $\mathrm{mL}$ dan dimasukkan ke dalam labu ukur 100 $\mathrm{mL}$ dan ditambahkan aqua DM hingga batas. Larutan dikocok dan diukur absorbansinya menggunakan AAS. Data absorbansi yang diperoleh dibuat kurva kalibrasi antara absorbansi (y) dan konsentrasi (x). Prosedur 
diatas dilakukan juga untuk konsentrasi larutan standar $\mathrm{Cr}^{6+}$ sebanyak 3 ppm dan 5 ppm.

\subsection{Pengukuran Kadar Cr (VI) dalam Air} Sampel Sungai Jagir

Larutan sampel air sungai Jagir diambil sebanyak $50 \mathrm{~mL}$ dan ditambahkan dengan 5

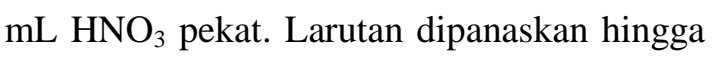
sisa volumenya $20 \mathrm{~mL}$. Kemudian, ke dalam larutan ditambahkan $7 \mathrm{~mL} \quad \mathrm{HNO}_{3}$ dengan dikocok dan selanjutnya dipanaskan selama 10 menit. Larutan dipindahkan kedalam labu ukur $50 \mathrm{~mL}$ setelah disaring terlebih dahulu menggunakan kertas saring. Selanjutnya, larutan tersebut ditambahkan aqua DM hingga batas.

\subsection{Pengukuran Suhu dan pH Air Sampel} Sungai Jagir

Larutan sampel air sungai Jagir diambil sebanyak $100 \mathrm{~mL}$ dan diletakkan dalam gelas beaker. Kemudian diukur suhu air menggunakan termometer dan dicatat suhunya. Larutan sampel diukur pH air awal menggunakan $\mathrm{pH}$ meter dan dicatat $\mathrm{pH}$ yang terukur.

\subsection{Pengujian Absorbsi Ion Cr(VI) oleh} Biosorben

Pektin kulit jeruk manis (Citrus sinensis) kering ditimbang sebanyak $0,5 \mathrm{~g}$ dan dimasukkan kedalam $50 \mathrm{~mL}$ larutan sampel air sungai Jagir. Larutan dihomogenkan menggunakan shaker dengan kecepatan 250 rpm dengan variasi waktu 1,2, dan 3 jam. Larutan didekantasi menggunakan pipet tetes untuk memisahkan supernatan dengan biosorben. Supernatan yang diperoleh kemudian diuji AAS untuk mengetahui kandungan logam yang masih tersisa dalam air. Prosedur tersebut dilakukan lagi untuk variasi pektin sebesar $1 \mathrm{~g}$ dan $1,5 \mathrm{~g}$. Biosorben yang telah digunakan kemudian dikeringkan menggunakan oven pada suhu $40^{\circ} \mathrm{C}$ selama 8 jam. Pektin kering dianalisa menggunakan FTIR untuk mengetahui rusak tidaknya struktur pektin setelah digunakan sebagai biosorben logam.

\subsection{Perhitungan Daya Serap Pektin}

\section{Terhadap Logam}

Persentase daya serap biosorben terhadap logam dapat ditentukan dengan persamaan 2.1 .

$\%$ penyerapan $=\left[\frac{\left(\mathrm{L}_{\mathrm{b}-} \mathrm{L}_{\mathrm{s}}\right)}{\mathrm{L}_{\mathrm{b}}}\right] \mathrm{x} 100 \%$

Dengan:

$\mathrm{Lb}=$ konsentrasi sampel $\mathrm{Cr}(\mathrm{VI})$ sebelum diabsorb

Ls = konsentrasi sampel Cr (VI) setelah diabsorb

\section{Hasil dan Pembahasan}

\subsection{Pembuatan Absorben Bubuk Pektin dari} Kulit Jeruk Manis (Citrus sinensis)

Kulit jeruk yang digunakan sebagai sumber pektin berwarna oranye tua dengan struktur permukaan yang halus. Kulit jeruk tersebut merupakan limbah buangan dari penjual es jeruk peras. Suhu yang digunakan pada ekstraksi pektin adalah $80{ }^{\circ} \mathrm{C}$ dengan waktu perendaman selama 40 menit. Hal ini 
didasarkan pada penelitian terdahulu yang dilakukan oleh Suryaningtyas (2012) [9] yang memberikan hasil kadar metoksil terendah pektin adalah pada suhu ekstraksi $80{ }^{\circ} \mathrm{C}$ dengan waktu 40 menit. Pektin yang diperoleh berbentuk bubuk halus, berwarna kuning kecoklatan dan tidak larut dalam etanol.

Pektin dikatakan bermetoksil rendah apabila kadar metoksilnya kurang dari $7 \%$. Namun, pada penelitian ini tidak dilakukan pengujian kadar metoksil yang terkandung dalam pektin kulit jeruk manis. Menurut Constenla (2003) [10], kadar metoksil yang rendah dapat digunakan sebagai absorben logam berat karena ion logam bivalen dapat bereaksi dengan gugus-gugus karboksil dari dua molekul asam pektat dan membentuk jembatan yang akan mengikat ion-ion dari logam berat dalam suatu larutan. Bubuk pektin kering kemudian dianalisa dengan menggunakan spektrofotometer Inframerah (IR). Analisa dilakukan untuk mengetahui apakah pektin benar-benar terekstrak atau tidak. Spektra IR bubuk pektin sebelum digunakan pada proses absorbsi dan setelah digunakan dalam proses absorbsi dapat dilihat pada Gambar 3.1.

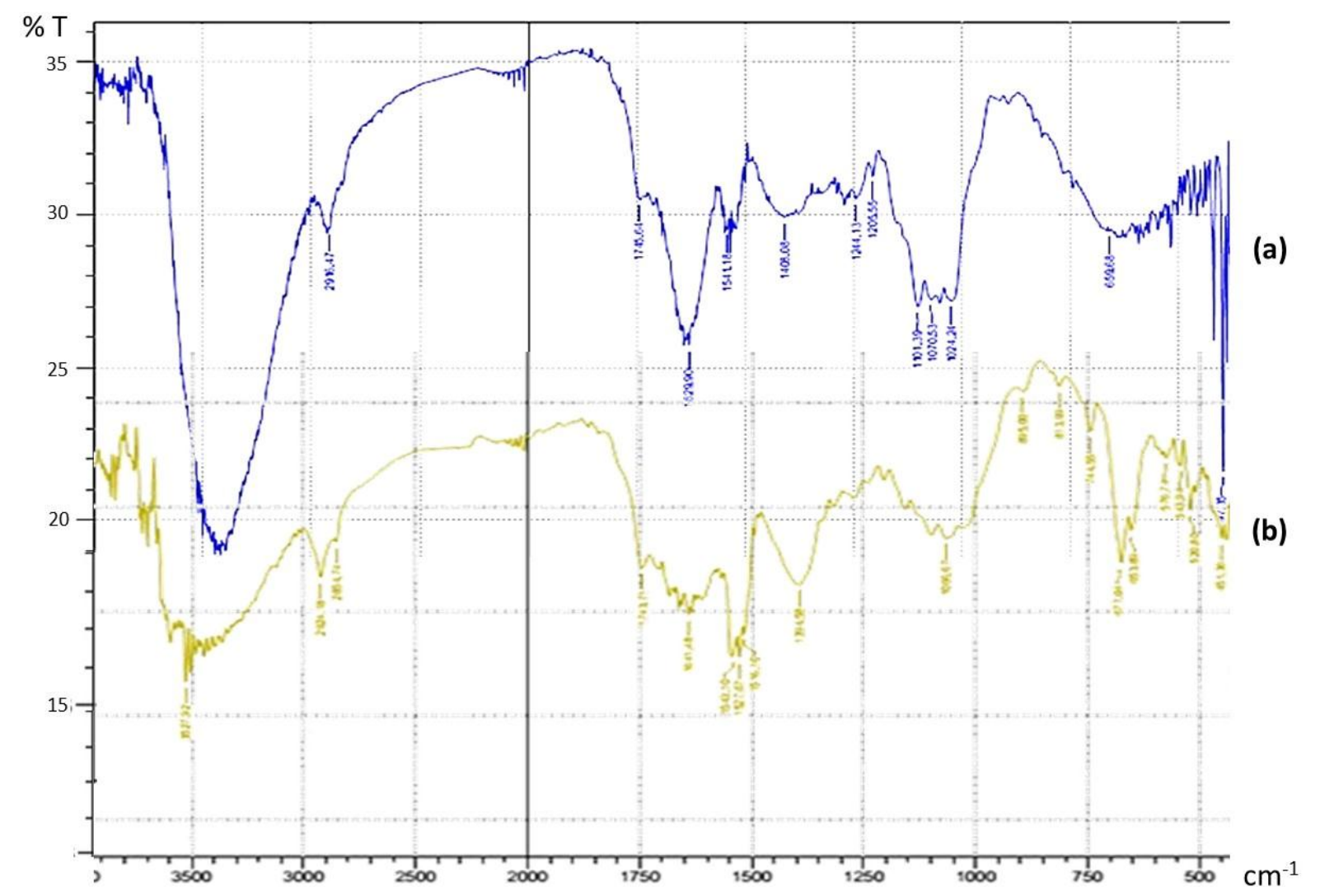

Gambar 3.1 Hasil FTIR Bubuk Pektin (a) sebelum absorbsi, (b) setelah absorbsi. 


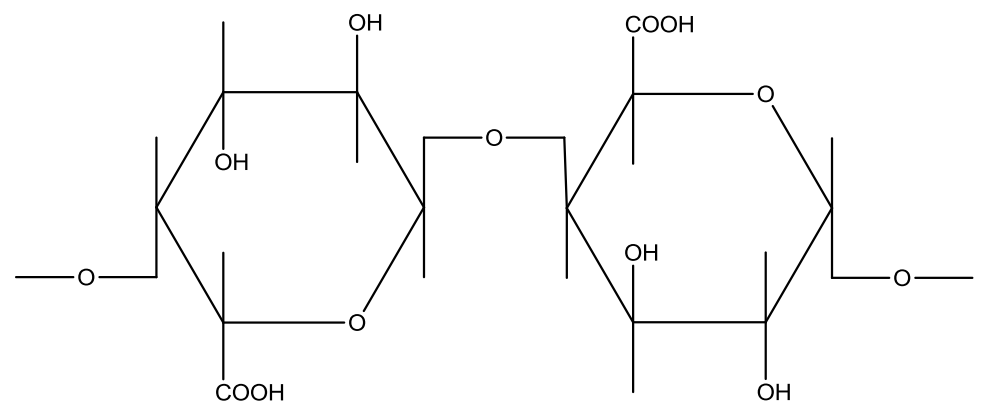

Gambar 3.2 Struktur Pektin

Gambar 3.1 menunjukan adanya gugus $\mathrm{OH}$-asam diserapan $3433,41 \mathrm{~cm}^{-1}$. Selain itu, terdapat serapan $\mathrm{C}-\mathrm{H}$ alkana di daerah 2916,47 $\mathrm{cm}^{-1}, \mathrm{C}=\mathrm{O}$ asilhalida di daerah $1745,64 \mathrm{~cm}^{-1}$ dan $\mathrm{C}=\mathrm{C}$ alkena di daerah serapan $1629,90 \mathrm{~cm}^{-1}$. Jika ditinjau kembali dengan gugus pektin menunjukkan bahwa serbuk pektin pada penelitian ini terbentuk. Gambar struktur pektin kulit jeruk manis dapat dilihat pada Gambar 3.2

\subsection{Pembuatan Kurva Kalibrasi Cr(VI)}

Kurva kalibrasi Cr (VI) dibuat dengan menggunakan variasi larutan standar $\mathrm{Cr}(\mathrm{VI})$ sebesar 1 ppm, 3 ppm, dan 5 ppm. Hasil absorbansi larutan standar tersebut dibuat kurva kalibrasi dengan tujuan untuk mengetahui hubungan antara absorbansi dan konsentrasi. Pembuatan kurva kalibrasi dengan sumbu $\mathrm{x}$ berupa konsentrasi dan sumbu y adalah absorbansi dan didapatkan persamaan $\mathrm{y}=0,0284 \mathrm{x}-0,0006$.

\subsection{Pengukuran Kadar Ion Cr(VI) Pada Sampel Sungai Air Jagir}

Sampel air sungai Jagir dikocok dengan tujuan agar larutan homogen. Penambahan asam nitrat bertujuan untuk melarutkan analit logam dan menghilangkan zat-zat pengganggu yang terdapat dalam sampel air. Penyaringan menggunakan kertas saring dilakukan untuk memisahkan pengotor yang masih tersisa dalam larutan sampel. Dari pengukuran menggunakan AAS, didapatkan konsentrasi $\mathrm{Cr}$ awal sebelum dilakukan absorbsi adalah sebesar 0,2532 ppm. Selain itu, dilakukan pengukuran suhu dan $\mathrm{pH}$ air sungai. Pengukuran suhu air dilakukan menggunakan termometer dan didapatkan suhu air sebesar $31^{\circ} \mathrm{C}$. Pengukuran $\mathrm{pH}$ air dilakukan menggunakan $\mathrm{pH}$ meter dan didapatkan $\mathrm{pH}$ air sebesar 6,5.

\subsection{Absorbsi Ion Cr(VI) Pada Sampel Sungai} Air Jagir menggunakan Pektin

Larutan logam ditambahkan pektin dengan berat pektin yang berbeda yaitu $0,5 \mathrm{~g}$, $1 \mathrm{~g}$, dan $1,5 \mathrm{~g}$ dan diaduk menggunakan shaker dengan variasi waktu 1 jam, 2 jam, dan 3 jam. Pektin yang telah bercampur air sungai Jagir berwarna merah keruh yang disebabkan terjadinya pembentukan senyawa kompleks antara logam $\mathrm{Cr}(\mathrm{VI})$ dan pektin. 
Larutan ini selanjutnya dipisahkan dengan menggunakan prinsip dekantasi. Supernatan yang diperoleh kemudian diukur kadar logam Cr(VI) menggunakan spektrofotometer serapan atom (AAS). Konsentrasi Cr(VI) yang tersisa dalam sampel air sungai Jagir setelah proses absorbsi yang dapat dilihat pada Tabel 3.1. Dari data konsentrasi sebelum dan setelah absorbsi, dapat dihitung daya serap pektin terhadap logam $\mathrm{Cr}(\mathrm{VI})$ seperti yang ditunjukkan pada Tabel 3.2.

Pada Tabel 3.2 terlihat peningkatan persentase penyerapan yang sebanding dengan peningkatan waktu kontak dan massa pektin yang digunakan untuk absorbsi. Daya serap terbesar terjadi pada waktu kontak 3 jam dan massa pektin 1,5 g dengan nilai persentase $98.06 \%$. Semakin lama logam dikontakkan dengan permukaan sel pektin maka akan semakin banyak permukaan sel yang menjadi aktif dan melakukan pengikatan terhadap logam. Pengikatan logam oleh pektin karena adanya gugus aktif yang memiliki pasangan elektron bebas terhadap ion $\mathrm{Cr}(\mathrm{VI})$ sehingga ion $\mathrm{Cr}(\mathrm{VI})$ dapat tertarik dan berikatan membentuk kompleks pektin dan logam [11]. Interaksi antara ion $\mathrm{Cr}(\mathrm{VI})$ dan pektin dapat dilihat pada Gambar 3.3.
Pektin yang telah digunakan untuk absorpsi dikarakterisasi lagi menggunakan spektrofotometer. Gambar 3.1 merupakan spektrum IR pektin setelah digunakan untuk mengabsorb ion $\mathrm{Cr}(\mathrm{VI})$. Pada gambar 3.1 diketahui bahwa terjadi perbedaan perubahan gugus pada pektin kulit Jeruk setelah mengalami absorbsi ion logam pada sampel air sungai Jagir. Dari hasil IR juga terdapat gugus OH-asam diserapan 3433,41 $\mathrm{cm}^{-1}$. Menurut penelitian Herdigenarosa pada tahun 2013 [12], terdapat gugus OH-asam di serapan $3431,5 \mathrm{~cm}^{-1}$. Serapan C-H alkana di daerah 2916,47 $\mathrm{cm}^{-1}, \mathrm{C}=\mathrm{O}$ ester di daerah 1745,64 $\mathrm{cm}^{-1}$ dan $\mathrm{C}=\mathrm{C}$ alkena di daerah serapan $1629,90 \mathrm{~cm}^{-1}$. Dari spektra IR pektin sebelum dan setelah absorpsi terdapat perbedaan intensitas dari keduanya.

Hasil FTIR struktur pektin yang telah mengalami absorbsi dapat dilihat bahwa terjadi perubahan struktur. Hal ini terjadi kemungkinan pektin sebagai absorben telah terlampau jenuh, sehingga daya serap akan semakin menurun karena permukaan tidak cukup kuat untuk mengikat kation logam yang tersisa dalam larutan.

Tabel 3.1. Data Konsentrasi $\mathrm{Cr}(\mathrm{VI})$ dalam Air Sungai Jagir Setelah Absorbsi

\begin{tabular}{|l|l|l|l|}
\hline \multirow{2}{*}{$\begin{array}{c}\text { Lama Waktu } \\
\text { Perendaman (jam) }\end{array}$} & \multicolumn{3}{|c|}{ Konsentrasi Cr(VI) yang terukur (ppm) } \\
\cline { 2 - 4 } & $\mathbf{0 , 5}$ & $\mathbf{1}$ & $\mathbf{1 , 5}$ \\
\hline 1 & 0,1138 & 0,0964 & 0,0684 \\
\hline 2 & 0,0649 & 0,0370 & 0,0230 \\
\hline 3 & 0,0405 & 0,0224 & 0,0049 \\
\hline
\end{tabular}


Tabel 3.2. Daya Serap Pektin Ion Cr(VI)

\begin{tabular}{|l|l|l|l|}
\hline \multirow{2}{*}{$\begin{array}{c}\text { Lama Waktu } \\
\text { Perendaman (jam) }\end{array}$} & \multicolumn{3}{|c|}{ Daya serap pektin (\%) dengan penambahan variasi } \\
berat pektin (g)
\end{tabular}

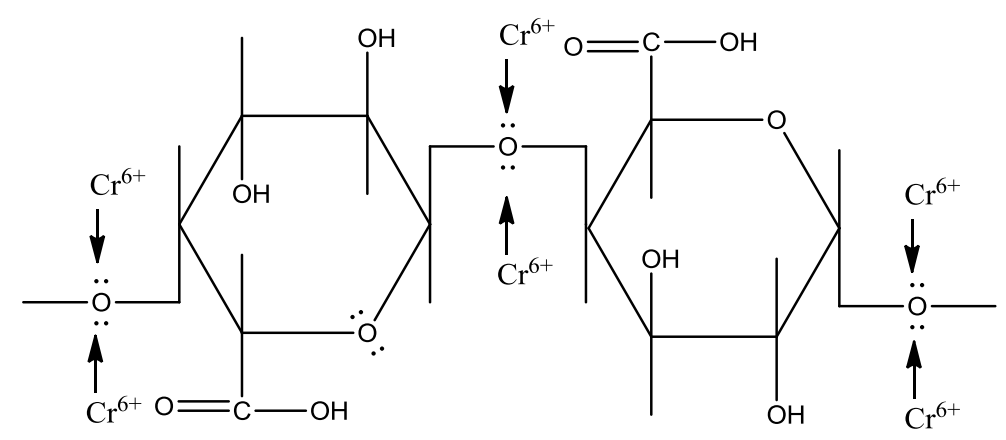

Gambar 3.3 Interaksi antara bubuk pektin dan ion $\mathrm{Cr}(\mathrm{VI})$

\section{Kesimpulan}

Bubuk pektin kulit jeruk manis dapat mengabsorb ion $\mathrm{Cr}$ (VI) pada sampel sungai air Jagir. Daya serap optimum sebesar 98.06\% didapat pada variasi massa 1,5 g dan waktu kontak selama 3 jam. Daya serap meningkat dengan meningkatnya waktu kontak dan massa pektin yang ditambahkan.

\section{Ucapan Terima Kasih}

Ucapan terimakasih penulis tujukan kepada Laboratorium Fundamental, Departemen Kimia, FIA, ITS.

\section{Daftar Pustaka}

[1] Kusnadi, S.B., "Studi Kualitas Fisika-Kimia Perairan dan Struktur Komunitas
Makrozoobenthos di Sungai Cikaniki, Kabupaten Bogor" Skripsi, Program Studi Manajemen Sumberdaya Perairan, Fakultas Perikanan dan Ilmu Kelautan, Institut Pertanian Bogor, Bogor, 99, 2002.

[2] Agustiningsih, Dyah, "Kajian Kualitas Air Sungai Blukar Kabupaten Kendal dalam Upaya Pengendalian Pencemaran Air Sungai", Tesis, Program Magister Ilmu Lingkungan Program Pasca Sarjana, Universitas Diponegoro Semarang, 2012.

[3] Suriawiria, U., "Mikrobiologi Air dan DasarDasar Pengolahan Buangan Secara Biologis", PT. Alumni, Bandung, 2003.

[4] Salmin, "Oksigen Terlarut (DO) dan Kebutuhan Oksigen Biologi (BOD) sebagai Salah Satu Indikator untuk Menentukan 
Kualitas Perairan", Jurnal Oseana, 30, 3, 21-26, 2005.

[5] Peraturan Pemerintah Republik Indonesia Nomor 82 Tahun 2001 tentang Pengelolaan Air dan Pengendalian Pencemaran Air.

[6] Royanudin, M., "Penetapan kadar kromium di sungai Surabaya dan kaitannya terhadap parameter kualitas air", Skripsi, Jurusan Kimia, Universitas Negeri Malang, 2008.

[7] Keputusan Menteri Kesehatan No. 907/MENKES/SK/VII/2002 tentang Syaratsyarat dan Pengawasan Kualitas Air Minum.

[8] Anggraini, A.S.P., "Penyisihan Kromium Pada Limbah Cair dengan Menggunakan Unggun Filtrasi Pasir", Program Studi Teknik Kimia, Universitas Tribhuwana Tunggadewi, Malang, 2012.
[9] Suryaningtyas, N.W.Y., Yulianti, L.I.M., Atmodjo, P.K., "Kemampuan Pektin Kulit Jeruk Manis (Citrus sinensis) sebagai Biosorben Logam Berat Krom (VI)", Program Studi Biologi, Fakultas Teknobiologi, Universitas Atma Jaya, Yogyakarta, 2012.

[10] Constenla, D., and Lozano, J.E., "Kinetic Model of Pectin Demethylation", Latin American Applied Research, No. 33, pp. 9196, 2003.

[11] Endress, H.U., "Nonfood Use of Pectin", Neuenburg, Hebstreith and Fox Kg PectinFabric, Germany, 1991.

[12] Herdigenosa, M., "Pembuatan Edible Coating dari Pektin Kulit Buah Jeruk Bali (Citrus maxima) dengan Variasi Sorbitol sebagai Plasticizer, Universitas Islam Negeri Sunan Kalijaga, Yogyakarta, 2013. 